ISSN 2080-1653

DOI 10.24917/20801653.322.16

\title{
JACEK Pluta
}

Uniwersytet Wrocławski, Polska

University of Wroclaw, Poland

\section{ŁUKASZ DAMURSKI}

Politechnika Wrocławska, Polska

Wroclaw University of Science and Technology, Poland

\section{JERZY ŁADYSZ}

Uniwersytet Ekonomiczny we Wrocławiu, Polska

Economics University in Wroclaw, Poland

WAWRZYNIEC ZIPSER

Politechnika Wrocławska, Polska

Wroclaw University of Science and Technology, Poland

MAgDALENA MAYER-WYdRA

Politechnika Wrocławska, Polska

Wroclaw University of Science and Technology, Poland

\section{AgNIESZKA KRIESEL}

Politechnika Wrocławska, Polska

Wroclaw University of Science and Technology, Poland

\section{Struktura potrzeb użyłkowników lokalnych centrów ustugowych w różnych kontekstach osadniczych. Studium porównawcze pl. I.L. Pereca we Wroctawiu i rynku w Siechnicach}

\section{The Structure of Users' Needs in Local Service Centres in Urban and Suburban Settlements. Comparative Study of I.L. Pereca Square in Wroctaw and Siechnice Main Square (Poland)}

\begin{abstract}
Streszczenie: Celem pracy jest rozpoznanie codziennych potrzeb mieszkańców obszarów zurbanizowanych w Polsce oraz ocena możliwości ich zaspokojenia w lokalnych (osiedlowych) centrach usługowych, rozumianych jako wielofunkcyjne przestrzenie publiczne zapewniające dostęp do podstawowych usług, sprzyjające integracji społecznej i budowaniu tożsamości lokalnej mieszkańców. Mając na uwadze zróżnicowaną dynamikę rozwoju osadniczego kraju, do badania wytypowano tereny reprezentujące różne formy przestrzenne obszarów zurbanizowanych: część dużego miasta i część miejscowości podmiejskiej. Badanie przeprowadzone metodą ankietową w czerwcu i lipcu 2017 roku na pl. I.L. Pereca we Wrocławiu i na rynku w Siechnicach (łącznie 232 respondentów) pozwala określić strukturę potrzeb użytkowników, praktyki ich zaspokajania oraz deficyty w zakresie usług. Zestawienie wyników dla społeczności lokalnych w mieście i na przedmieściach daje szeroki obraz relacji między sposobem zagospodarowania przestrzeni publicznych a codziennym funkcjonowaniem ich użytkowników w różnych kontekstach osadniczych. Artykuł potwierdza potrzebę tworzenia lokalnych centrów usługowych jako istotnego narzędzia w kształtowaniu jakości życia w obszarach zurbanizowanych i staje się przyczynkiem do wypracowania uniwersalnych rozwiązań funkcjonalno-przestrzennych sprzyjających budowaniu silnych społeczności lokalnych w Polsce.
\end{abstract}


Abstract: The aim of the paper is to define the everyday needs of citizens in urban areas and to evaluate the potential for satisfying them in local (neighbourhood) service centres defined as multi-functional public spaces offering access to basic services, enabling social integration and building territorial identity of residents. Bearing in mind the diverse dynamics of urban development in Poland, the research refers to two typical forms of urban settlement: a neighbourhood in a big city and a suburban neighbourhood. The research conducted in June and July 2017 in I.L. Pereca Square in Wrocław and in Siechnice Main Square (232 respondents in total) enables to draw a structure of users' needs, the practices of satisfying them and deficits in the field of everyday services. A comparison of the results for local communities in a big city and in suburbs provides a wide picture of relationships between the development of public spaces and actual functioning of their users in various settlement contexts. The paper confirms the need for building and supporting local service centres as an important tools for shaping quality of life in urban areas. It also gives a reasoning for elaborating some universal solutions for building strong local communities in Poland.

Słowa kluczowe: lokalne centrum usługowe; osiedla miejskie; osiedla podmiejskie; potrzeby; Siechnice; usługi; Wrocław

Keywords: local (neighbourhood) service centre; needs; services; Siechnice; suburban neighbourhoods; urban neighbourhoods; Wroclaw

Otrzymano: 18 grudnia 2017

Received: 18 December 2017

Zaakceptowano: 18 maja 2018

Accepted: 18 May 2018

\section{Sugerowana cytacja / Suggested citation:}

Pluta, J., Damurski, Ł., Ładysz, J., Zipser, W., Mayer-Wydra, M., Kriesel, A. (2018). Struktura potrzeb użytkowników lokalnych centrów usługowych w różnych kontekstach osadniczych. Studium porównawcze pl. I.L. Pereca we Wrocławiu i rynku w Siechnicach. Prace Komisji Geografii Przemysłu Polskiego Towarzystwa Geograficznego, 32(2), 229-244. https://doi.org/10.24917/20801653.322.16

\section{LOKALNE CENTRUM USŁUGOWE - GENEZA I DEFINICJA}

Charakterystyczną, naturalną cechą usług jest ich koncentrowanie się w określonych lokalizacjach. Koncentracja z jednej strony umożliwia klientom zaspokojenie różnych potrzeb w jednym miejscu, a z drugiej - gwarantuje usługodawcom opłacalność prowadzonej działalności (Zipser, 1983). Zjawisko to można zaobserwować w różnych skalach (regionalnej, ogólnomiejskiej, dzielnicowej, osiedlowej), a jego uniwersalność i powszechność zasadza się na dwóch cechach: znacznym nagromadzeniu urządzeń i obiektów o charakterze instytucjonalnym, kulturalnym, handlowym i usługowym, co stwarza okazję do załatwienia kilku spraw za jednym razem, oraz oferowaniu zestawu obiektów i urządzeń unikatowych, co daje możliwość załatwienia określonych spraw jedynie w tym miejscu (por. Brzosko-Sermak, Płaziak, Trzepacz, 2017).

Szczególną formą takiej koncentracji jest lokalne centrum usługowe (w skrócie: LCU), które można zdefiniować jako wielofunkcyjną przestrzeń publiczną zapewniającą dostęp do podstawowych (codziennych) usług, sprzyjającą integracji społecznej i budowaniu tożsamości lokalnej mieszkańców. LCU nabierają obecnie szczególnego znaczenia w związku z obserwowanym w krajach wysoko rozwiniętych odchodzeniem od urbanizacji ilościowej na rzecz jakościowej, która poprzez rewitalizację istniejących przestrzeni publicznych i dostosowywanie ich oferty do potrzeb użytkowników dąży do podniesienia jakości życia w miastach i na przedmieściach (por. Domaradzka, Sadowy, 2015).

Archetypem (pierwowzorem) lokalnego centrum usługowego, jako przestrzeni publicznej kumulującej życie społeczne, do dziś pozostaje ateńska agora. Źródeł idei 
LCU należy zatem poszukiwać w starożytnych greckich polis, gdzie główny plac miejski łączył w sobie różnego rodzaju obiekty: świątynie, bibliotekę, stoły handlowe, arsenał itd., będąc tym samym miejscem spotkań i wymiany (zarówno handlowej, jak i metafizycznej - wymiany myśli). Później, w okresie średniowiecza, bardzo podobne funkcje, pomimo odmiennych warunków społecznych, religijnych, politycznych i gospodarczych, pełniły niewielkie, uporządkowane i świadomie projektowane miasta lokacyjne, z ich rynkami otoczonymi zabudową pierzejową, wyposażonymi w różne obiekty towarzyszące (kościół, targ) (Ostrowski, 2001). Ten wzorzec, kontynuowany w kolejnych epokach, utrwalił zestaw charakterystycznych cech miejskiego centrum usługowego jako przestrzeni publicznej oferującej określony zakres usług (handel, administracja, finanse, religia, kultura, rozrywka itp.).

Dopiero era przemysłowa z jej szybką, masową i początkowo bezplanową urbanizacją zatraciła ludzki wymiar miasta, zaburzając tym samym naturalne procesy koncentracji usług i prowadząc do niedorozwoju struktur urbanistycznych opartych na sąsiedztwie komplementarnych funkcji, a w efekcie do zatracenia pierwotnej roli centrum lokalnego jako czynnika strukturalnego, organizującego przestrzeń osiedli mieszkaniowych. Szukając odpowiedzi na problemy tej epoki, moderniści stworzyli szereg koncepcji teoretycznych zmierzających do odwrócenia niekorzystnych trendów w rozwoju miast i przywrócenia wielofunkcyjności osiedli miejskich. Szczególne miejsce zajmuje wśród nich jednostka sąsiedzka C. Perry’ego, której celem było stworzenie osiedla funkcjonalnego, samowystarczalnego (przynajmniej w podstawowym zakresie) i oferującego pożądaną jakość życia. Wielkość jednostki (między 5 tys. a 9 tys. mieszkańców) i jej forma przestrzenna były zdeterminowane przez promień dojścia pieszego do szkoły zlokalizowanej w centrum w taki sposób, by dojście do niej nie wymagało przekraczania głównych arterii komunikacyjnych. Lokalne sklepy umiejscowiono w rejonie głównej przestrzeni wejściowej do osiedla (Perry, 1998).

Uniwersalność koncepcji jednostki sąsiedzkiej sprawiła, że stała się ona punktem odniesienia dla późniejszych modeli kształtowania LCU, w tym dla idei współczesnej agory promowanej przez F. van Klingerena w latach sześćdziesiątych i siedemdziesiątych XX wieku. Zgodnie $\mathrm{z}$ tym podejściem centrum osiedlowe ma być miejscem integracji społecznej, umożliwiającym wymianę wiedzy oraz kultywowanie różnorodnych aktywności i zainteresowań. Program funkcjonalno-przestrzenny współczesnej agory nie musi być przeznaczony dla konkretnej grupy ludzi - powinien raczej być otwarty, elastyczny i dawać możliwość dopasowania do bieżących potrzeb różnych użytkowników w cyklu dnia, tygodnia, miesiąca i roku (Kowicki, 2004).

\section{REPERTUAR POTRZEB REALIZOWANYCH W LCU W WYNIKACH WCZEŚNIEJSZYCH BADAŃ}

W przytoczonej wcześniej definicji lokalnego centrum usługowego istotne jest to, że jako przestrzeń urządzona, wyposażona w „meble miejskie”, sprzyjająca przebywaniu ludzi LCU jest w skali osiedla wartością dodaną i wyróżnia się z bezpośredniego otoczenia. Nie jest to przestrzeń duża pod względem powierzchni, gdyż nastawiona jest na zaspokojenie potrzeb względnie małej liczby osób - mieszańców osiedla, kwartału zabudowy - ale jednocześnie jest to przestrzeń celowo wytworzona, będąca ramą dla różnych funkcji, również prospołecznych, integrujących. 
Jak zauważa D. Mantey (2015), analizę potencjału przestrzeni w zakresie realizacji określonych potrzeb mieszkańców należy prowadzić na dwóch płaszczyznach: przestrzennej (gdzie ważny jest sam sposób zagospodarowania przestrzeni) i społecznej (skupiającej się na użytkownikach przestrzeni, ich stylu życia i wartościach). Taki właśnie schemat opisu przyjęto $\mathrm{w}$ tym artykule, łącząc materialne wyposażenie LCU z jego oceną przez mieszkańców.

Podstawową populacją, której ekonomiczne i społeczne potrzeby ma zaspokajać LCU, jest ta, w której więzi społeczne odpowiadają koncepcji lokalnej wspólnoty jako formy zwielokrotnionego sąsiedztwa, opartego na bezpośrednich i względnie częstych interakcjach międzyludzkich. W ujęciu ilościowym można taką zbiorowość oszacować na 2 do 10 tys. mieszkańców (Borsa, 2016), gdzie czas dojścia od miejsca zamieszkania do LCU nie powinien przekraczać 10 minut.

Mechanizm koncentracji opiera się w dużej mierze na popycie, czyli repertuarze potrzeb danej społeczności oraz środkach, jakimi dysponuje (por. Zipser, 1983; Flejterski, Panasiuk, Perenc, Rosa, 2005). Dlatego jednym z głównych wątków w opisie LCU będą funkcje spełniane w układzie zasobów oraz potrzeb społeczności lokalnej, co z kolei odsyła nas do pojęcia jakości życia.

Można wyróżnić trzy integralne komponenty globalnej jakości życia człowieka: sferę fizyczną (potrzeby fizyczne, biologiczne, fizjologiczne), sferę psychiczną (potrzeby bezpieczeństwa, przynależności, szacunku, poznawcze) oraz sferę duchową (potrzeby estetyczne, samorealizacji i transcendencji) (Borys, Rogala, 2008). Oczywiście zadaniem LCU nie jest zaspokojenie wszystkich potrzeb użytkowników, ale ów globalny repertuar potrzeb pozostaje ważnym punktem odniesienia dla konceptualizacji problematyki badań w tej dziedzinie. Niezaprzeczalne jest wszakże to, że ogólnodostępna przestrzeń interakcji i integracji w sąsiedztwie miejsca zamieszkania jest ważnym elementem jakości życia (Mantey, 2015).

Ogólnopolskie badania CBOS dotyczące oczekiwań Polaków względem miejsca zamieszkania wskazują, że w ostatnich latach struktura potrzeb w tym zakresie podlega powolnym zmianom. Rośnie znaczenie otoczenia miejsca zamieszkania: respondenci pytani o czynniki ważne przy wyborze nowego lokum coraz częściej akcentują ilość zieleni i wolnej przestrzeni, obecność szkoły i przedszkola oraz przestrzeni publicznych (rynek, park, plac) (CBOS, 2010).

Istotnym nurtem $\mathrm{w}$ rozpoznawaniu potrzeb mieszkańców jest bez wątpienia metoda pracy środowiskowej (Faliszek, Kowalczyk, Mandrysz, Leśniak-Berek, Wódz, 2010), w której organizacja środowiska lokalnego mieszkańców następuje w oparciu o istniejące zasoby przestrzenne. Powszechnie stosowany w tym zakresie standard CAL (Centrum Wspierania Aktywności Lokalnej, 2017) służy sporządzaniu map zasobów i potrzeb oraz powiązanych z nimi katalogów deficytów oraz problemów społecznych i przestrzennych w miejscach zamieszkania.

Cennym doświadczeniem na drodze do identyfikacji potrzeb mieszkańców był projekt Analiza Funkcjonalna Osiedli (Dom Pokoju, 2016), który pozwolił na wskazanie kluczowych deficytów jakości życia w przestrzeniach zamieszkiwania we Wrocławiu. Dotyczyły one przede wszystkim rozwiązań poprawiających funkcjonalną użyteczność przestrzeni zamieszkiwania w zakresie dostępu do infrastruktury komunikacyjnej i usług, poprawy czystości i estetyki, podnoszenia spójności społecznej (integracji sąsiedzkiej, poczucia bezpieczeństwa) i poszerzania możliwości spędzania czasu 
wolnego. Na podstawie tych obserwacji można za D. Mantey stwierdzić, że „im więcej lokalnych sklepów i punktów usługowych, obiektów sportowych, szkół, parków i kościołów, tym większa szansa tworzenia więzi i wzajemnych zależności między ludźmi" (Mantey, 2015: 30-31). Wszystko to wskazuje na rosnącą potrzebę kształtowania LCU jako punktów węzłowych osiedlowego habitatu, zaspokajających podstawowe, codzienne potrzeby mieszkańców.

\section{Cel i ZAKRES BADAŃ}

Celem pracy jest rozpoznanie codziennych potrzeb mieszkańców obszarów zurbanizowanych w Polsce oraz ocena możliwości ich zaspokojenia w lokalnych (osiedlowych) centrach usługowych. Mając na uwadze zróżnicowaną dynamikę rozwoju osadniczego kraju, do badania wytypowano tereny reprezentujące różne formy przestrzenne obszarów zurbanizowanych: część dużego miasta i część miejscowości podmiejskiej. Podjęte pytania badawcze brzmią następująco:

1. jakie potrzeby użytkowników zaspokaja, a jakich nie zaspokaja lokalne centrum usługowe i dlaczego,

2. jakie różnice występują między potrzebami użytkowników w mieście i na przedmieściach.

Jako przykład osiedla wielkomiejskiego wybrano Gajowice we Wrocławiu, gdzie pl. I.L. Pereca tworzy silne, historycznie ugruntowane LCU w zabudowie kamienicowej i częściowo blokowej, z usługami na parterze, z trójkątnym placem i odchodzącym od niego czytelnie zarysowanym układem ulic i chodników. Centralną częścią LCU jest skrzyżowanie ulic z obszernym, urządzonym i odgrodzonym placem zabaw w otoczeniu drzew. Zakres oferowanych usług w okolicy pl. Pereca obejmuje sklepy, drobne rzemiosło, pocztę, przedszkole, banki, bibliotekę i niewielkie lokale gastronomiczne (cukiernia, kawiarnia), choć bez restauracji i pubów. Bezpośrednim zapleczem placu jest mniejsza przestrzeń międzyblokowa, w której zlokalizowano dyskont wielobranżowy (ryc. 1).

Z kolei jako przykład struktury podmiejskiej wybrano rynek w Siechnicach - nową przestrzeń zorganizowaną $\mathrm{w}$ formie dużego placu pieszego $\mathrm{z}$ ratuszem, otoczonego blokami zabudowy wielorodzinnej z usługami na parterze. Dominantą przestrzeni jest plac z wyeksponowanym budynkiem ratusza - miejscem załatwiania spraw urzędowych - po jednej stronie i kościołem po drugiej stronie. Na urządzenie placu składają się ławki oraz ustawione w szeregu wielofunkcyjne budki przeznaczone na prowadzenie działalności handlowej o charakterze targowym w wybrane dni tygodnia. Bezpośrednie otoczenie placu stanowi zabudowa pierzejowa, składająca się z nowo wybudowanych budynków mieszkalnych typu niski blok, w części z lokalami parterowymi przeznaczonymi dla handlu. Wśród najemców dominują oferenci usług gastronomicznych (kawiarnia, cukiernia, piekarnia) oraz banki. Dalsze linie zabudowy (w odległości $50 \mathrm{~m}$ ) tworzą stare, typowe dla Siechnic domy jednorodzinne i budynki w zabudowie zagrodowej (ryc. 2).

Wytypowane obszary są zbliżone pod względem skali i funkcjonalności, co daje dobre podstawy do prowadzenia badań porównawczych. Istotną różnicą jest jednak kontekst. Wrocław jako duże miasto posiada zaawansowaną i rozbudowaną (co najmniej trzystopniową) strukturę centrów usługowych, podczas gdy Siechnice to jednostka 
Ryc. 1. Kategorie usług w LCU pl. I.L. Pereca we Wrocławiu (stan na maj 2017)

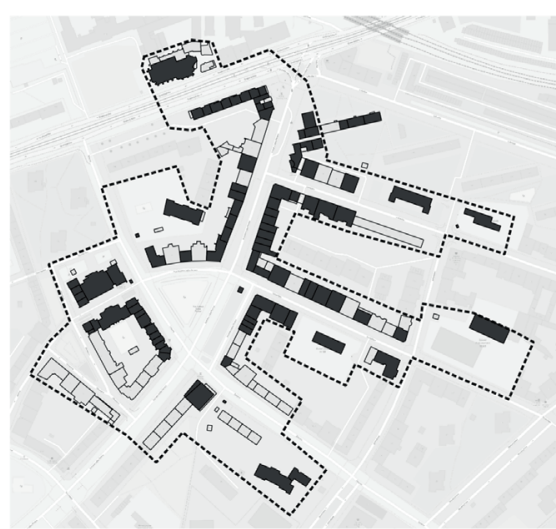

-- Granica opracowania

Usługi

Budynki nieusługowe

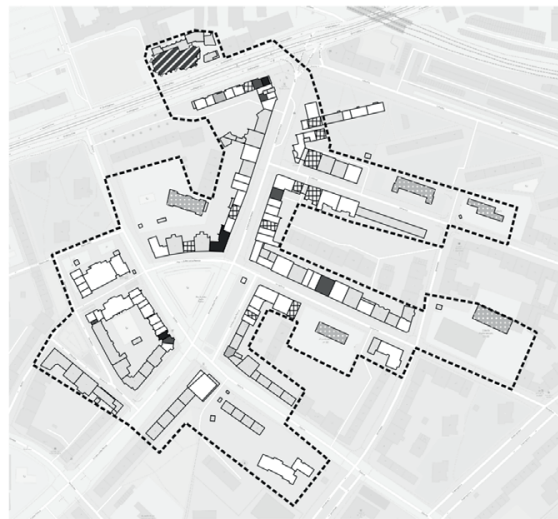

-- Granica opracowania

Usługi publiczne, sakralne i pozostałe

Edukacja

Poczta

Kościół

Bank

世冊 Drobna usługa związana z rzemiosłem

Usługa specjalistyczna

Inna usługa

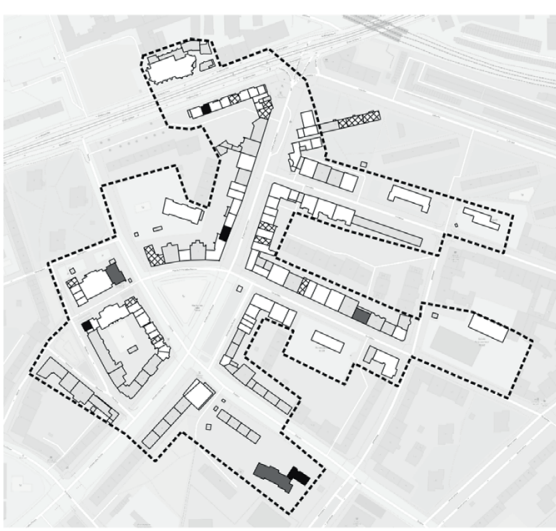

Granica opracowania

Zdrowie i uroda

Ochrona zdrowia

Apteka

Drobne usługi związane z urodą

Inne usługi

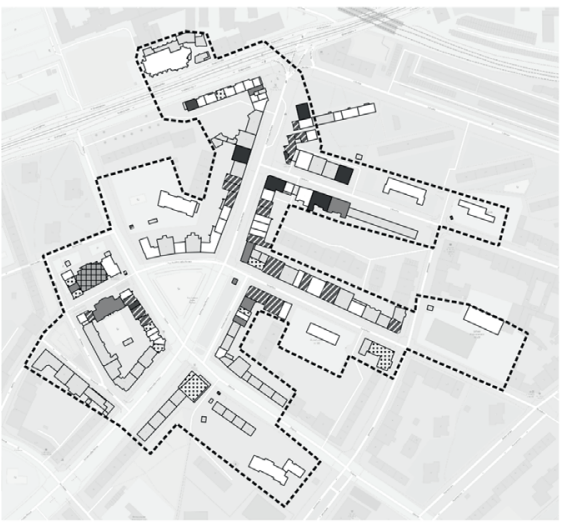

-- Granica opracowania

Handel i gastronomia

UIA Sklep spożywczy

巴 Dyskont spożywczy

Gastronomia

:::: Sklep odzieżowy

Salonik prasowy

Sklep specjalistyczny

Inna usługa 
Ryc. 2. Kategorie usług w LCU na rynku w Siechnicach (stan na czerwiec 2017)

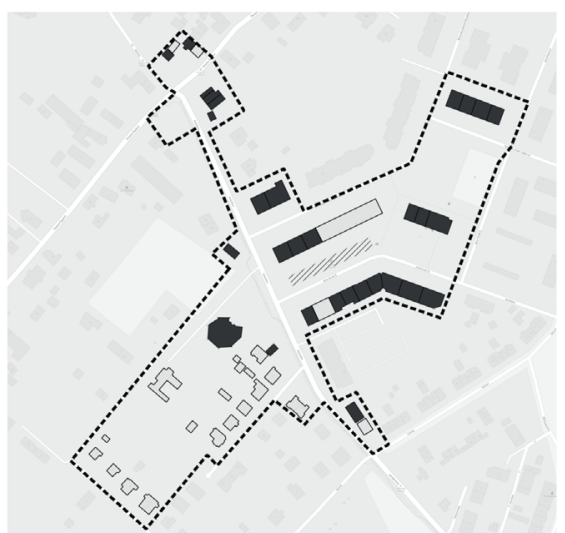

-E granica opracowania

Usługi

Plac targowy

Budynki nieusługowe

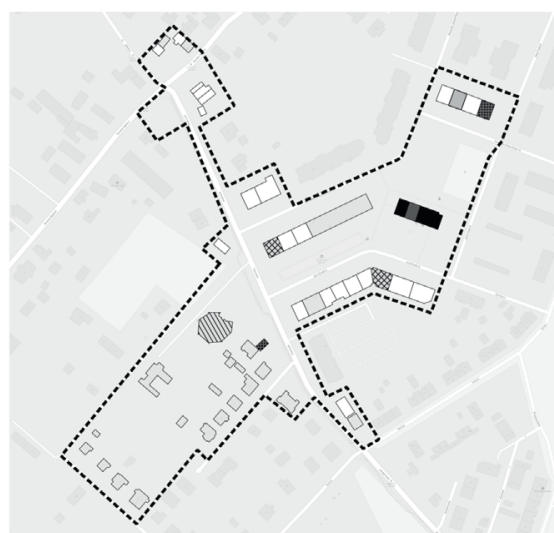

U.:- Granica opracowania

Usługi publiczne, sakralne i pozostałe

Administracja i bezpieczeństwo

Edukacja

Poczta

MIIV Kościół

Bank

패:퓨: Drobna usługa związana z rzemiosłem

$\square$ Inna usługa

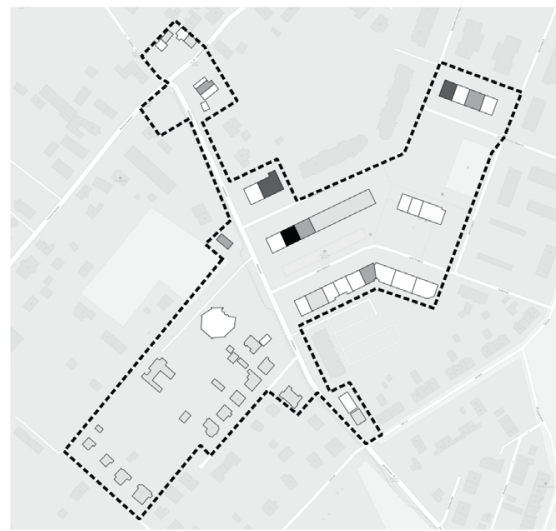

-1 Granica opracowania

Zdrowie i uroda

Ochrona zdrowia

Apteka

Drobna usługa związana z urodą

Inna usługa 
wybitnie suburbialna pod względem przestrzennym, społecznym i gospodarczym, należąca do wrocławskiego obszaru funkcjonalnego i pod wieloma względami zależna od stolicy Dolnego Śląska. Siechnicki rynek pełni funkcję LCU, ponieważ w pobliżu nie istnieje alternatywna przestrzeń o podobnym potencjale - najbliższa konkurencja to centra usługowe wyższej rangi we Wrocławiu.

Trzeba również zauważyć, że przyjęty dobór obszarów do badań nie uprawnia do generalizowania uzyskanych wyników. Plac Pereca we Wrocławiu i siechnicki rynek to stosunkowo dobrze funkcjonujące LCU, które w oczywisty sposób nie oddają wszystkich możliwych sytuacji. Na przykład opisany ostatnio przez A. Brzosko-Sermak, M. Płaziaka i P. Trzepacza (2017) przypadek krakowskiej Nowej Huty, gdzie nawet rewitalizacja nie zdołała zahamować spadku liczby funkcji handlowo-usługowych, pokazuje, że na skutek starzenia się i ubożenia społeczeństwa, wolnorynkowej konkurencji oraz braku restrykcyjnej polityki przestrzennej bardziej tętniące życiem i przyciągające użytkowników w związku z codziennymi sprawunkami okazują się duże centra handlowe ze sklepami wielkopowierzchniowymi i targowiska niż zaprojektowane, historycznie ugruntowane przestrzenie urbanistyczne predysponowane do pełnienia funkcji ośrodków usługowych (Brzosko-Sermak, Płaziak, Trzepacz, 2017). Stąd interpretacja prezentowanych w tym artykule badań wymaga ostrożności.

\section{METODY BADAŃ}

W artykule przedstawiono wyniki badań przeprowadzonych pomiędzy majem a lipcem 2017 roku w rejonie pl. Pereca we Wrocławiu i rynku w Siechnicach, zdefiniowanych jako lokalne centra usługowe. Pomiary przeprowadzono metodą ankietową wśród użytkowników LCU, to jest mieszkańców z obszarów bezpośrednio przylegających do terenu badań oraz osób odwiedzających LCU. Wielkość uzyskanej próby badawczej wyniosła ogółem 232 osoby, z czego 159 z Wrocławia i 73 z Siechnic (tab. 1).

Tab. 1. Struktura próby przyjętej do badań wyrażona za pomocą liczby wypełnionych ankiet w poszczególnych grupach respondentów oraz procentowego udziału w ogólnej liczbie wykonanych pomiarów

\begin{tabular}{|l|c|c|c|}
\cline { 2 - 4 } \multicolumn{1}{c|}{} & $\begin{array}{c}\text { pl. Pereca } \\
\text { we Wrocławiu }\end{array}$ & $\begin{array}{c}\text { Rynek } \\
\text { w Siechnicach }\end{array}$ & Ogółem \\
\hline \multirow{2}{*}{ Wersja „a" przechodnie } & 64 & 30 & 94 \\
\cline { 2 - 4 } & $40,3 \%$ & $41,1 \%$ & $40,5 \%$ \\
\hline \multirow{2}{*}{ Wersja „b" lokatorzy } & 95 & 43 & $59,5 \%$ \\
\cline { 2 - 4 } & $59,7 \%$ & $58,9 \%$ & 232 \\
\hline \multirow{2}{*}{ Ogółem } & 159 & 73 & $100,0 \%$ \\
\hline
\end{tabular}

Źródło: opracowanie własne

W pomiarze wykorzystano kwestionariusz wywiadu i ankiety składający się z siedmiu pytań związanych z problematyką badań oraz czterech pytań metryczkowych o różnym stopniu złożoności (jednokrotnego, wielokrotnego wyboru oraz jednego pytania otwartego i mapki). Sposób organizacji pomiaru był dwojaki. Po pierwsze, 
ankietowano przechodniów w wytypowanych uprzednio (w drodze wizji lokalnej) miejscach LCU związanych $\mathrm{z}$ ich różną funkcjonalnością w stosunku do możliwości zaspokajania potrzeb (robienie zakupów, korzystanie z usług, spotkania, wypoczynek i rekreacja). Pomiar zrealizowano przez przeszkolonych ankieterów i polegał on na aranżacji wywiadu z wytypowanymi w sposób losowy osobami z zastosowaniem metody typowania systematycznego (poprzez typowanie co n-tej osoby przechodzącej przez obszar działania ankietera).

Drugą metodą wykorzystującą to samo narzędzie było rozdawanie ankiet w wytypowanych ciągach mieszkalnych (punktach lokalowych gospodarstw osób fizycznych), usytuowanych w bezpośredniej bliskości rejonu badań. Ten sposób pomiaru polegał na rozdawaniu w kopercie kwestionariusza do samodzielnego wypełnienia, a następnie na powtórnej wizycie w krótkim odstępie czasu i odebraniu wypełnionej ankiety. Tym samym w uzyskanej ostatecznie próbie można rozróżnić kategorię lokatorów i przechodniów. Odsetek lokatorów w obydwu próbach był wyrównany.

\section{WYNIKI BADAŃ: LCU JAKO MIEJSCE ZASPOKAJANIA POTRZEB}

Rozpatrywanie roli i znaczenia LCU dla lokalnej społeczności winno, w pewnym choćby stopniu, uwzględniać ewentualną alternatywę. W referowanych badaniach kwestię tę ujęto poprzez złożone pytanie, w którym respondentom przedstawiono do oceny różne czynności związane z zaspokajaniem potrzeb warunkowanych przez dostęp do zasobów. Posługując się skalą odpowiedzi, w której wyróżniono zarówno samo LCU, jak i jego otoczenie (bliższe i dalsze), respondenci mogli wskazać tylko jedno z miejsc dla każdej z usług (tab. 2).

Porównanie roli i pozycji dwóch LCU w strukturze zaspokajanych potrzeb ujawnia znaczące różnice między przedmieściami a dużym miastem. Generalny wniosek, jaki można wysnuć, jest taki, że siechnicki rynek w znacząco mniejszym stopniu narażony jest na konkurencję ze strony otoczenia zewnętrznego. Wykaz usług bezpośrednio załatwianych w miejscu LCU prezentuje tab. 3. Ponadto w obrębie LCU użytkownicy korzystają z tych usług, dla których konkurencja nie ma większego znaczenia (bankomat, poczta, podstawowy sklep spożywczy, miejsce zabaw dzieci, strefa wyprowadzania psów), ponieważ i tak najważniejsza jest bliskość przestrzenna - codziennych usług szuka się w najbliższym sąsiedztwie.

W przeciwieństwie do wrocławskiego placu Pereca, który przegrywa najczęściej konkurencję z miastem jako takim (inną częścią miasta), siechnicki rynek i jego najbliższe otoczenie jest bezpośrednim miejscem zaspokajania większego spektrum usług. Z kolei plac Pereca - co bezpośrednio wynika z jego funkcji - jest częściej wskazywany jako miejsce spacerów z psem oraz spacerów z dziećmi.

Natomiast wspólną cechą obydwu LCU jest to, że nie są one pierwszym wskazywanym miejscem dla spotkań towarzyskich i miejsc spędzania czasu wolnego, co jest zbieżne z obserwacjami D. Mantey (2015), która stwierdza, że pomimo istnienia przestrzeni publicznych mieszkańcy rzadko z nich korzystają, co obniża poziom kapitału społecznego i uniemożliwia budowanie poczucia wspólnoty. Być może jest więc tak, że spędzanie czasu wolnego nie należy do funkcji pełnionych przez LCU, że tego typu potrzeby realizowane są poza lokalnym habitatem. Ten zaskakujący wniosek wymaga jednak jeszcze potwierdzenia w dalszych badaniach. 


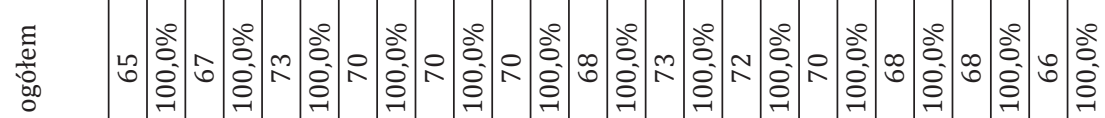

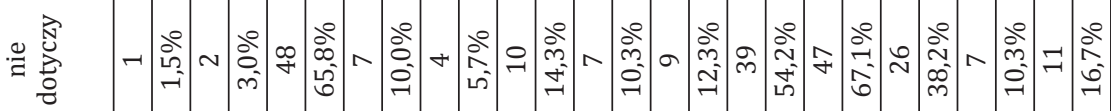

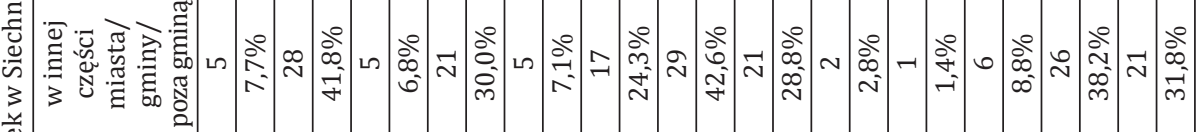

$\stackrel{5}{5}$

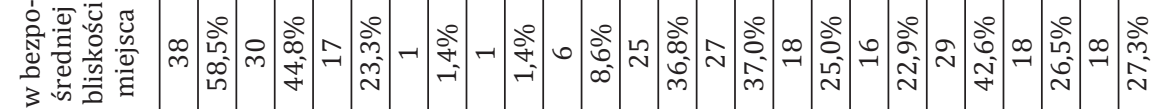

:

हี z

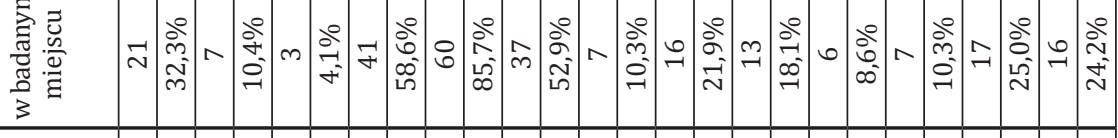

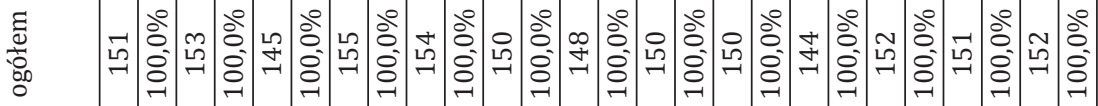

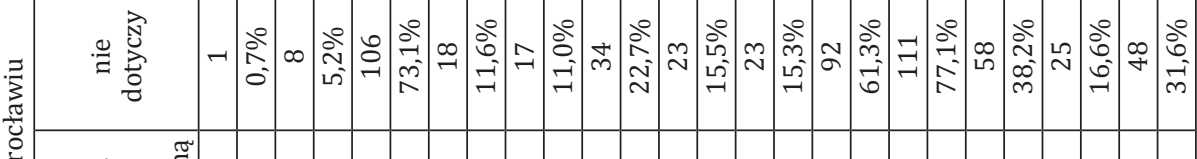

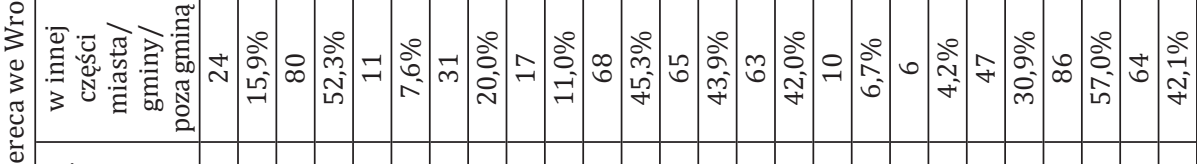

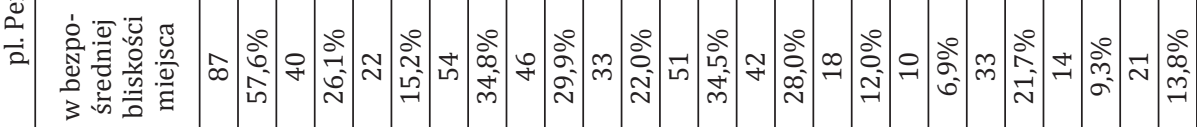

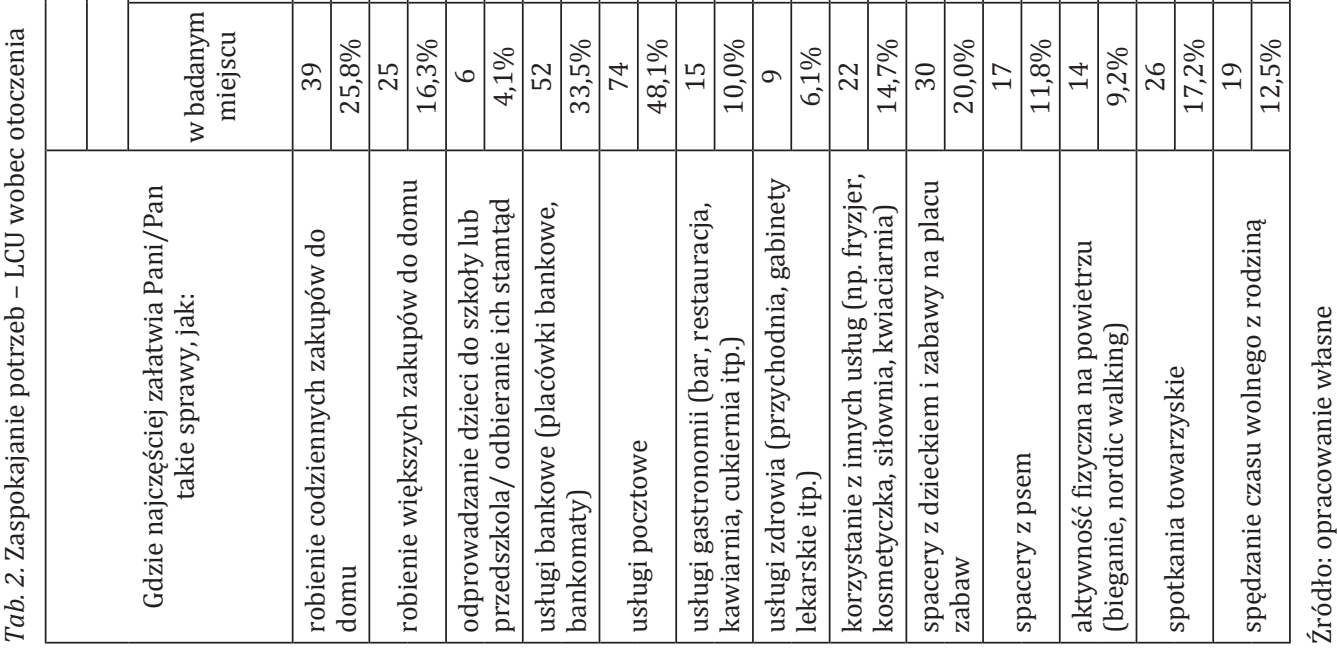


Tab. 3. Pierwszeństwo zaspokajanych potrzeb: w LCU czy poza LCU?

\begin{tabular}{|c|c|c|}
\hline Czynność & pl. Pereca we Wrocławiu & Rynek w Siechnicach \\
\hline $\begin{array}{l}\text { Robienie codziennych zakupów } \\
\text { do domu }\end{array}$ & W bezpośrednim otoczeniu LCU & W bezpośrednim otoczeniu LCU \\
\hline $\begin{array}{l}\text { Robienie większych zakupów do } \\
\text { domu }\end{array}$ & Inna część miasta/gminy & $\begin{array}{l}\text { W bezpośrednim otoczeniu LCU = } \\
\text { inna część miasta/gminy }\end{array}$ \\
\hline $\begin{array}{l}\text { Odprowadzanie dzieci do szkoły } \\
\text { lub przedszkola i odbieranie ich } \\
\text { stamtąd }\end{array}$ & $\begin{array}{l}\text { Nie dotyczy > w bezpośrednim } \\
\text { otoczeniu LCU }\end{array}$ & $\begin{array}{l}\text { Nie dotyczy > w bezpośrednim } \\
\text { otoczeniu LCU }\end{array}$ \\
\hline $\begin{array}{l}\text { Usługi bankowe (placówki } \\
\text { bankowe, bankomaty) }\end{array}$ & $\begin{array}{l}\text { W bezpośrednim otoczeniu LCU = } \\
\text { w tym LCU }\end{array}$ & W tym LCU \\
\hline Usługi pocztowe & W tym LCU & W tym LCU \\
\hline $\begin{array}{l}\text { Usługi gastronomii (bar, } \\
\text { restauracja, kawiarnia, cukiernia } \\
\text { itp.) }\end{array}$ & Inna część miasta/gminy & W tym LCU \\
\hline $\begin{array}{l}\text { Usługi zdrowia (przychodnia, } \\
\text { gabinety lekarskie itp.) }\end{array}$ & Inna część miasta/gminy & Inna część miasta/gminy \\
\hline $\begin{array}{l}\text { Korzystanie z innych usług } \\
\text { (np. fryzjer, kosmetyczna, } \\
\text { siłownia, kwiaciarnia) }\end{array}$ & Inna część miasta/gminy & W bezpośrednim otoczeniu LCU \\
\hline $\begin{array}{l}\text { Spacery z dzieckiem i zabawy na } \\
\text { placu zabaw }\end{array}$ & Nie dotyczy > w tym LCU & $\begin{array}{l}\text { Nie dotyczy > w bezpośrednim } \\
\text { otoczeniu LCU }\end{array}$ \\
\hline Spacery z psem & Nie dotyczy $>$ w tym LCU & $\begin{array}{l}\text { Nie dotyczy > w bezpośrednim } \\
\text { otoczeniu LCU }\end{array}$ \\
\hline $\begin{array}{l}\text { Aktywność fizyczna na powietrzu } \\
\text { (bieganie, nordic walking) }\end{array}$ & $\begin{array}{l}\text { Nie dotyczy > inna część miasta/ } \\
\text { gminy }\end{array}$ & $\begin{array}{l}\text { W bezpośrednim otoczeniu LCU > } \\
\text { nie dotyczy }\end{array}$ \\
\hline Spotkania towarzyskie & Inna część miasta/gminy & Inna część miasta/gminy \\
\hline $\begin{array}{l}\text { Spędzanie czasu wolnego } \\
\text { z rodziną }\end{array}$ & Inna część miasta/gminy & Inna część miasta/gminy \\
\hline
\end{tabular}

Źródło: opracowanie własne

\section{WYNIKI BADAŃ: NIEZASPOKOJONE POTRZEBY ORAZ OCZEKIWANE KIERUNKI ZMIAN}

Ankietowanych uczestników badań poproszono także o krótką wypowiedź swobodną na temat postulowanych propozycji zmian w ich otoczeniu. Uzyskane wyniki poddano analizie treści i skategoryzowano w postaci pytania zamkniętego, którego rozkład odpowiedzi prezentuje tab. 4 .

Tab. 4. Braki w wyposażeniu LCU i niezbędne zmiany w przestrzeni

\begin{tabular}{|l|c|c|c|}
\hline \multicolumn{1}{|c|}{ Czego brakuje w tym rejonie? } & $\begin{array}{c}\text { pl. Pereca } \\
\text { we Wrocławiu }\end{array}$ & $\begin{array}{c}\text { Rynek } \\
\text { w Siechnicach }\end{array}$ & Ogółem \\
\hline \multirow{2}{*}{ sklepy drobne różnych typów } & 14 & 30 & 44 \\
\cline { 2 - 4 } & $8,8 \%$ & $41,1 \%$ & 10 \\
\hline \multirow{2}{*}{ duży sklep wielobranżowy } & 6 & 4 & 23 \\
\hline \multirow{2}{*}{ gastronomia } & $3,8 \%$ & $5,5 \%$ & \\
\hline \multirow{2}{*}{ miejsca spotkań i spędzania czasu wolnego } & 12 & 11 & 35 \\
\cline { 2 - 4 } & $7,5 \%$ & 10 & \\
\hline
\end{tabular}




\begin{tabular}{|c|c|c|c|}
\hline \multirow{2}{*}{ zieleń, miejsca rekreacji i uprawiania sportów } & 25 & 11 & 36 \\
\hline & $15,7 \%$ & $15,1 \%$ & \\
\hline \multirow{2}{*}{ parkingi } & 9 & 0 & 9 \\
\hline & $5,7 \%$ & $0,0 \%$ & \\
\hline \multirow{2}{*}{ plac zabaw i inne atrakcje dla dzieci } & 4 & 2 & 6 \\
\hline & $2,5 \%$ & $2,7 \%$ & \\
\hline \multirow{2}{*}{ usługi dla ludności } & 3 & 3 & 6 \\
\hline & $1,9 \%$ & $4,1 \%$ & \\
\hline \multirow{2}{*}{ braki infrastruktury i złe zagospodarowanie terenu } & 14 & 7 & 21 \\
\hline & $8,8 \%$ & $9,6 \%$ & \\
\hline \multirow{2}{*}{ nic/ jest wszystko } & 15 & 7 & 22 \\
\hline & $9,4 \%$ & $9,6 \%$ & \\
\hline \multirow{2}{*}{ inne } & 19 & 0 & 19 \\
\hline & $11,9 \%$ & $0,0 \%$ & \\
\hline \multirow{2}{*}{ brak wskazania } & 50 & 16 & 66 \\
\hline & $31,4 \%$ & $21,9 \%$ & \\
\hline Ogółem & 159 & 73 & 232 \\
\hline
\end{tabular}

Źródło: opracowanie własne

Poziom oczekiwań wydaje się korespondować ze zidentyfikowaną strukturą potrzeb. Co charakterystyczne, propozycje zmian i uzupełnień w wyposażeniu LCU są znacznie bardziej wyraźne w przypadku Siechnic, mimo iż teoretycznie siechnicki rynek był częściej wskazywanym miejscem zaspokajania codziennych potrzeb. Być może społeczność Siechnic postrzega przestrzeń przez pryzmat wielkiego miasta i stąd wyższe aspiracje mieszkańców i użytkowników, którzy od siedziby gminy oczekują czegoś więcej niż tylko placu i kilku punktów usługowych.

Istotny może być tu również kontekst miejsca i jego położenie względem tego, co oferuje otoczenie. 0 ile w przypadku placu Pereca mamy wzmożoną konkurencję innych części miasta, o tyle w odniesieniu do rynku w Siechnicach brakuje liczącej się alternatywy, co powoduje tym większe poczucie deficytów w badanym miejscu, zwłaszcza jeśli chodzi o sklepy wielobranżowe czy usługi gastronomiczne (lokale i restauracje). Z kolei w przypadku zieleni oraz urządzonych miejsc aktywnego spędzania czasu wolnego i rekreacji poziom deficytów był podobny i w obu analizowanych przypadkach drugi w kolejności pod względem znaczenia.

\section{WNIOSKI}

Zestawienie wyników dla społeczności lokalnych w mieście i na przedmieściach daje szeroki obraz relacji między sposobem zagospodarowania przestrzeni publicznych a codziennym funkcjonowaniem ich użytkowników w różnych kontekstach osadniczych. Lokalne centrum usługowe w oczywisty sposób nie zaspokaja wszystkich potrzeb mieszkańców: wiele z nich jest realizowanych poza LCU. Jednocześnie jako przestrzeń publiczna wyróżniająca się z otoczenia jest ono naturalnym miejscem koncentracji działalności usługowych i posiada realny potencjał do wzbogacenia oferty zgodnie z oczekiwaniami użytkowników.

Niewielka liczebność próby i specyfika obszarów wytypowanych do badań z pewnością nie uprawniają do generalizacji uzyskanych wyników. Można jednak wysunąć 
wstępne wnioski dotyczące hierarchii usług w różnych kontekstach osadniczych. I tak, usługi, których obecność w bezpośredniej bliskości miejsca zamieszkania jest dla użytkowników istotna, to sklepy (codzienne zakupy do domu), placówki edukacyjne (przedszkola, szkoły), usługi finansowe (placówki bankowe, bankomaty) oraz usługi pocztowe. Wśród deficytów szczególnie widoczny jest niedobór usług zdrowia, zieleni, miejsc spotkań i spędzania czasu wolnego - dotyczy on obu badanych lokalizacji.

Istotne różnice w ocenie stopnia realizacji potrzeb między miastem a przedmieściami pojawiają się w zakresie usług gastronomii i drobnych usług rzemieślniczych (np. fryzjer, kosmetyczna, siłownia, kwiaciarnia) - w tym zakresie lepiej wypada oferta podmiejskich Siechnic, zapewne w związku z brakiem alternatywy w otoczeniu. Z kolei oferta Wrocławia lepiej zaspokaja potrzeby związane z codziennymi zakupami, co wydaje się naturalne zważywszy na większą skalę całego założenia.

Artykuł potwierdza potrzebę istnienia (a pośrednio również tworzenia i wspierania) lokalnych centrów usługowych jako narzędzia w kształtowaniu jakości życia w obszarach zurbanizowanych. Zaprezentowane wyniki badań nad LCU w różnych kontekstach osadniczych mogą być przyczynkiem do wypracowania uniwersalnych rozwiązań funkcjonalno-przestrzennych, sprzyjających budowaniu silnych społeczności lokalnych w Polsce.

\section{Literatura \\ References}

Borsa, M. (2016, 20 września). Pozyskano z www.m-borsa.net/edu

Borys, T., Rogala, P. (red.) (2008). Jakość życia na poziomie lokalnym - ujęcie wskaźnikowe. Warszawa: UNDP Polska.

Brzosko-Sermak, A., Płaziak, M., Trzepacz, P. (2017). Przemiany funkcji handlowych i usługowych centrum dzielnicy mieszkaniowej na przykładzie Krakowa-Nowej Huty. Prace Komisji Geografii Przemysłu Polskiego Towarzystwa Geograficznego, 31(2), 95-110.

CBOS (2010). Jak Polacy mieszkaja a jak chcieliby mieszkać. Komunikat z badań CBOS BS/120/2010. Warszawa.

Centrum Wspierania Aktywności Lokalnej (2017, 29 lipca). Pozyskano z www.cal.org.pl

Dom Pokoju (2016, 2 listopada). Pozyskano z http://www.lokietka5.pl/badanie-miejskie-analiza-funkcjonalna-wroclawskich-osiedli/

Domaradzka, A., Sadowy, K. (2015). Definicja i funkcje centrum lokalnego. W: Studium koncepcyjne dotyczq̨ce centrów lokalnych $w$ Warszawie. Warszawa: Wydawnictwo Oddziału Warszawskiego Stowarzyszenia Architektów Polskich, 10-15.

Faliszek, K., Kowalczyk, B., Mandrysz, W., Leśniak-Berek, E., Wódz, K. (2010). Programy aktywności lokalnej jako instrument aktywizacji środowiska lokalnego w rozwiązywaniu problemów mieszkańców. Przegląd Socjologiczny, 4, 29-60.

Flejterski, S., Panasiuk, A., Perenc, J., Rosa, G. (red.) (2005). Współczesna ekonomika usług. Warszawa: Wydawnictwo Naukowe PWN.

Kowicki, M. (2004). Współczesna agora. Wybrane problemy kształtowania ośrodków usługowych dla małych społeczności lokalnych. Kraków: Politechnika Krakowska.

Mantey, D. (2015). Miejsca spotkań w kontekście postmaterialistycznych wartości w suburbiach (przykład gmin Podkowa Leśna i Brwinów). Przestrzeń Społeczna (Social Space Journal), 2(10), 91-126.

OpenStreetMap (2017, 30 listopada). Pozyskano z https://www.openstreetmap.org/

Ostrowski, W. (2001). Wprowadzenie do historii budowy miast. Ludzie i środowisko. Warszawa: Oficyna Wydawnicza Politechniki Warszawskiej.

Perry, C. (1998). The Neighbourhood Unit, a Scheme for Arrangement for the Family-Life Community (1929). London: Reprinted Routledge/Thoemmes.

Zipser, T. (1983). Zasady planowania przestrzennego. Wrocław: Oficyna Wydawnicza Politechniki Wrocławskiej. 
Jacek Pluta, dr, socjolog, adiunkt w Instytucie Socjologii Uniwersytetu Wrocławskiego. Swoje zainteresowania naukowe lokuje w polu socjologii kultury, socjologii miasta, problemów społecznych, jakości życia oraz przedsiębiorczości. Specjalizuje się w opracowaniu i wdrażaniu metodologii projektów badawczych w obszarze stosowanych nauk społecznych (CAPI, PAPI, FGI). Jako ekspert szeroko współpracuje z instytucjami samorządowymi, NGO oraz podmiotami gospodarczymi w sektorze polityki społecznej, usług społecznych, kultury i organizacji czasu wolnego. Kierownik wielu projektów badawczych, w tym m.in. takich jak: „Ogólnopolskie badanie sytuacji, potrzeb i możliwości osób niepełnosprawnych” (2008-2010), „Strategie sukcesyjne polskich przedsiębiorstw rodzinnych” (2012-2013), „Czynniki rozwoju przedsiębiorczości na lokalnym rynku pracy” (2005-2007), „Ewaluacja Europejskiej Stolicy Kultury Wrocław 2016” (2016-2017), „Analiza funkcjonalna osiedli” (2015-2016), „Wrocławska diagnoza społeczna” (edycja 2010, 2014, 2017), „Strategia Kultura Obecna!” (2017), „Strategia Wrocław 2030” (2018). Autor i współautor książek: Atlas problemów społecznych Wrocławia (2006), My, Wrocławianie. Społeczna przestrzeń miasta (2006), Problemy społeczne w przestrzeni Wrocławia (2010), Stare i nowe problemy społeczne wielkiego miasta (2010), City and Power Postmodern Urban Spaces in Contemporary Poland (2018).

Jacek Pluta, Ph.D., assistant professor at the Institute of Sociology at the University of Wroclaw. His research interests are focused around the field of sociology of culture, urban sociology, social problems, quality of life and entrepreneurship. He specialises in preparing and implementing methodologies in applied social sciences (CAPI, PAPI, FGI). As an expert he widely cooperates with public authorities, NGOs and market actors in social policy, social services culture and free time organisation. He is a director of many research projects, including Ogólnopolskie badanie sytuacji, potrzeb i możliwości osób niepełnosprawnych (2008-2010), Strategie sukcesyjne polskich przedsiębiorstw rodzinnych (2012-2013), Czynniki rozwoju przedsiębiorczości na lokalnym rynku pracy (2005-2007), Ewaluacja Europejskiej Stolicy Kultury Wrocław 2016 (2016-2017), Analiza funkcjonalna osiedli (2015-2016), Wrocławska diagnoza społeczna (edycja 2010, 2014, 2017), Strategia Kultura Obecna! (2017), Strategia Wrocław 2030 (2018). He is an author and co-author of books: Atlas problemów społecznych Wrocławia (2006), My, Wrocławianie. Społeczna przestrzeń miasta (2006), Problemy społeczne w przestrzeni Wrocławia (2010), Stare i nowe problemy społeczne wielkiego miasta (2010), City and Power - Postmodern Urban Spaces in Contemporary Poland (2018).

\title{
Adres/address:
}

\author{
Uniwersytet Wrocławski \\ Instytut Socjologii \\ Zakład Socjologii Kultury i Cywilizacji \\ ul. Koszarowa 3, 51-149 Wrocław, p. 341 (budynek IS), Polska \\ e-mail: jacek.pluta@uwr.edu.pl
}

Łukasz Damurski, dr inż., urbanista, badacz i nauczyciel akademicki na Wydziale Architektury Politechniki Wrocławskiej (od 2006 roku). Jego zainteresowania badawcze oscylują wokół lokalnych (osiedlowych) centrów usługowych, komunikacji społecznej w planowaniu przestrzennym i kwestii e-planowania. Kierował licznymi projektami badawczymi w ramach grantów Komisji Europejskiej, Ministerstwa Nauki i Szkolnictwa Wyższego oraz Narodowego Centrum Nauki. Od 2014 roku jest członkiem międzynarodowej Rady Recenzentów w czasopiśmie „International Journal of E-Planning Research” (IJEPR). Jego prace - artykuły i książki dotyczące różnych aspektów planowania przestrzennego - charakteryzują się szerokim spojrzeniem uwzględniającym czynniki polityczne i aksjologiczne. Obecnie pracuje nad interdyscyplinarnym projektem badawczym dotyczącym lokalnych centrów usługowych w funkcjonalnych obszarach miejskich.

Łukasz Damurski, Ph.D., urban planner, post-doc researcher and academic teacher at the Faculty of Architecture, Wroclaw University of Science and Technology, Poland (since 2006). His research interests focus on local (neighbourhood) service centres, public communication in urban planning and e-planning issues. He has conducted numerous research projects funded within grant programmes from the European Commission, Polish Ministry of Science and National Research Centre Poland. Since 2014 he has been a member of the Editorial Review Board in the International Journal of E-Planning Research (IJEPR). His works - papers and books on various aspects of urban planning theory and practice - are characterised by a wide, political and axiological perspective. Currently he is working on a multi-disciplinary project on local service centres in functional urban areas. 


\title{
Adres/address:
}

Politechnika Wrocławska

Wydział Architektury

Katedra Urbanistyki i Procesów Osadniczych

ul. B. Prusa 53/55, pok. 120d, 50-317 Wrocław, Polska

e-mail: lukasz.damurski@pwr.edu.pl

Jerzy Ładysz, dr inż., ekonomista i urbanista, adiunkt w Katedrze Nauk o Przedsiębiorstwie na Uniwersytecie Ekonomicznym we Wrocławiu; absolwent Wydziału Gospodarki Narodowej Akademii Ekonomicznej we Wrocławiu oraz Wydziału Architektury Politechniki Wrocławskiej. Specjalizuje się w modelowaniu i optymalizacji lokalizacji obiektów usługowych, spójności terytorialnej, współpracy transgranicznej. Autor ponad 85 publikacji naukowych. Wykonawca kilku krajowych i międzynarodowych projektów badawczych.

Jerzy Ładysz, Ph.D., economist and urban planner, assistant professor at the Department of Enterprise Studies at the Wroclaw University of Economics; graduate of the Faculty of National Economy of the Wrocław University of Economics and the Faculty of Architecture at the Wrocław University of Science and Technology. He specializes in modelling and optimization of the location of service facilities, territorial cohesion and cross-border cooperation. Author of over 85 publications. Executant of several national and international research projects.

\section{Adres/address:}

\author{
Uniwersytet Ekonomiczny we Wrocławiu \\ Wydział Ekonomii, Zarządzania i Turystyki w Jeleniej Górze \\ Katedra Nauk o Przedsiębiorstwie \\ ul. Nowowiejska 3, 58-500 Jelenia Góra, Polska \\ e-mail: jerzy.ladysz@ue.wroc.pl
}

Wawrzyniec Zipser, dr inż., urbanista, adiunkt na Wydziale Architektury Politechniki Wrocławskiej. Pochodzi z Wrocławia, choć jego korzenie rodzinne odwołują się do ważnych dla urbanistyki miast: Lwowa i Pragi. Skończył studia w czwartym roczniku świeżo uruchomionego kierunku gospodarka przestrzenna na Wydziale Architektury Politechniki Wrocławskiej (jeden z dwu pierwszych w Polsce), tam też obronił w 2005 roku dysertację doktorską na temat wpływu handlu wielkopowierzchniowego na kształtowanie struktury miejskiej. Pracuje jako dydaktyk i pracownik naukowy w Katedrze Urbanistyki i Procesów Osadniczych Politechniki Wrocławskiej. Zajmuje się przede wszystkim szeroko ujętym problemem procesów osadniczych: w skali lokalnej po regionalną, stosuje narzędzia symulacyjne oraz systemy informacji przestrzennej.

Wawrzyniec Zipser, Ph.D., urban planner, assistant professor at the Faculty of Architecture at the Wroclaw University of Science and Technology. He was born in Wroclaw, although his family roots reach cities important for urban planning: Lviv and Prague. He has graduated from the newly-launched Spatial Management (one of the first two in Poland) at the Faculty of Architecture of the Wrocław University of Science and Technology where he obtained his doctoral title in 2005 based on a dissertation about the impact of large-scale retail on shaping the city structure. He works as a teacher and researcher at the Department of Urban Design \& Planning and Settlement Processes at the Wrocław University of Science and Technology. He deals mainly with the problems of settlement processes: on a local - regional scale, uses simulation tools and spatial information systems

\section{Adres/address:}

Politechnika Wrocławska

Wydział Architektury

Katedra Urbanistyki i Procesów Osadniczych

ul. B. Prusa 53/55, pok. 120d, 50-317 Wrocław, Polska

e-mail: wawrzyniec.zipser@pwr.edu.pl

Magdalena Mayer-Wydra, mgr inż., geograf i urbanista, doktorantka na Wydziale Architektury Politechniki Wrocławskiej, wykładowca Uniwersytetu Wrocławskiego. W swoich badaniach zajmuje się problematyką z zakresu struktury usługowej (handlowej) jednostek osadniczych, specyfiką miast poprzemysłowych, jakością przestrzeni publicznych oraz tożsamością miejsca. 
Magdalena Mayer-Wydra, M.Sc., geographer and town planner, Ph.D. candidate at the Faculty of Architecture at the Wroclaw University of Science and Technology. In her research she deals with problems of service (retail) structure of spatial units, post-industrial cities, quality of public spaces, place identity.

\title{
Adres/address:
}

\author{
Politechnika Wrocławska \\ Wydział Architektury \\ Katedra Urbanistyki i Procesów Osadniczych \\ ul. B. Prusa 53/55, pok. 17, 50-317 Wrocław \\ e-mail: magdalena.mayer@pwr.edu.pl
}

\begin{abstract}
Agnieszka Kriesel, mgr. inż., absolwentka studiów II stopnia na kierunku gospodarka przestrzenna na Wydziale Architektury Politechniki Wrocławskiej. Jej zainteresowania dotyczą szeroko pojętej rewitalizacji oraz kształtowania przestrzeni publicznych. Działa w Studenckim Kole Naukowym Gospodarki Przestrzennej, brała czynny udział w organizacji szkoły letniej we współpracy z firmą Here oraz w IV Kongresie Rewitalizacji Miast w Wałbrzychu. Obecnie jest stypendystką w ramach interdyscyplinarnego projektu badawczego „Model lokalnego centrum usługowego” finansowanego ze środków Narodowego Centrum Nauki.
\end{abstract}

Agnieszka Kriesel, B.Sc., graduate of Spatial Planning at the Faculty of Architecture, Wroclaw University of Science and Technology. Her research interest is connected with regeneration processes and shaping urban structures. She is a member of the Students Association of Spatial Planning. She co-organized a summer school with Here Company and worked as a volunteer on the $4^{\text {th }}$ Congress of Towns Regeneration in Wałbrzych, Poland. Currently she is a research fellow within a research project "Model of a local service centre" financed by National Science Centre Poland.

\section{Adres/address:}

Politechnika Wrocławska Wydział Architektury

Katedra Urbanistyki i Procesów Osadniczych ul. B. Prusa 53/55, pok. 17, 50-317 Wrocław

e-mail: agnieszka.kriesel@gmail.com

Artykuł prezentuje wstępne wyniki projektu badawczego „Model lokalnego centrum usługowego jako narzędzie kształtowania spójności terytorialnej obszarów miejskich” realizowanego na Wydziale Architektury Politechniki Wrocławskiej w latach 2016-2019 ze środków Narodowego Centrum Nauki (numer projektu 2015/19/B/HS4/01301). 